\title{
Morphology of the Dufour gland within the honey bee sting gland complex ${ }^{1}$
}

\author{
Stephen J. MARTIN ${ }^{a *}$, Vicky DILS $^{b}$, Johan BILLEN $^{b}$ \\ a Laboratory of Apiculture and Social Insects, Department of Animal and Plant Sciences, University of Sheffield, \\ Western Bank, Sheffield, S10 2TN, UK \\ b Zoological Institute, University of Leuven, Naamsestraat 59, B-3000, Leuven, Belgium
}

Received 29 November 2004 - revised 31 January 2005 - accepted 3 February 2005

Published online 13 September 2005

\begin{abstract}
The Dufour gland in the honeybee exits between the sting lancets. The exit is very narrow and indistinct, and is in the same position in both the queens and workers of the both Apis mellifera and Apis cerana. The gland's exit is close to the setosa membrane, a region of cuticle, which acts as a platform for pheromone release. This is consistent with the idea that the Dufour gland secretes compounds that are utilised in defence by workers or reproduction in queens.
\end{abstract}

Apis / honeybee / Dufour gland / sting / morphology

\section{INTRODUCTION}

The Dufour gland is associated with the sting apparatus in all female hymenoptera, an area utilized in defense by workers or reproduction in queens. In the honeybee the Dufour gland, previously called the basic or alkaline gland, is associated with the venom, sting sheath and Koschevnikov glands in the sting apparatus (see Fig. 1b). Despite several studies the precise role of the Dufour gland in honeybees is still unclear. The function of the gland has historically been based on the position of the glands' exits. Initially the Dufour gland exit was thought to be inside the sting bulb along with the venom gland (Bettini, 1978; Carlet, 1890; Snodgrass, 1925) as occurs in the ants (Billen, 1987), and the gland produced the alkaline component of the poison. Carlet (1890) indicated that for the poison to be effective both the alkaline and acid (from the venom 'acid' gland) secretions were required. Later, Heselhaus (1922) disputed this, and suggested that the alkaline secretion neutralised the acid remaining in the sting after stinging. Later studies showed the Dufour gland in fact opened outside the sting bulb probably near the sting lancets in the dorsal vaginal wall (de Lello, 1976; Billen, 1987). This finding that the Dufour gland's exit was close to the stinger and oviduct supported the idea that its role was the production of a sting lubricant (Gunnison and Morse, 1968), egg coating (Dufour, 1835; Trojan, 1930; Snodgrass, 1925), or egg marking pheromone (Ratnieks, 1995).

To understand better the role of the Dufour gland we carried out a morphological study to determine precisely the position of the glands exit in both Apis mellifera and Apis cerana worker and queen honey bees.

\section{METHOD}

A. mellifera and A. cerana foraging workers and mother queens were collected from colonies in Sheffield, UK and Matsumoto, Japan, respectively. The

\footnotetext{
* Corresponding author: s.j.martin@sheffield.ac.uk
}

${ }^{1}$ Manuscript editor: Klaus Hartfelder 

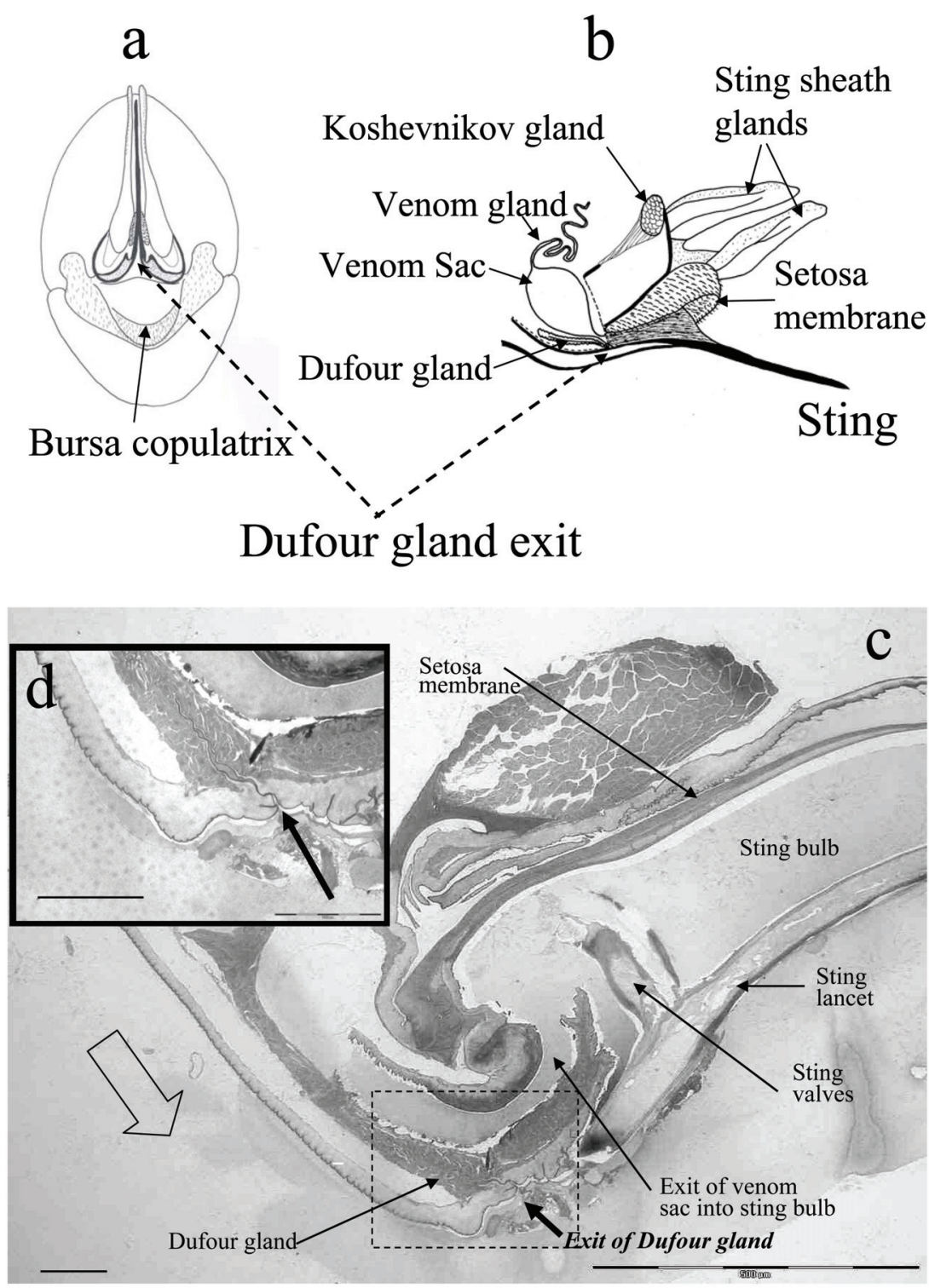

Figure 1. The position of the exit of the Dufour's gland in relation to the (a) queen sting (viewed end on), and (b) worker sting apparatus (side view). The relationship of the other glands in worker sting apparatus is also shown. The dotted lines represent a cut away area. The transverse section through an A. mellifera worker sting (c) shows the precise exit of the Dufour's gland (black arrow), enlarged in the insert (d), in relation to the sting. The passage of an egg during egg laying (clear arrow) is also illustrated. Scale bars are $100 \mu \mathrm{m}$ and $10 \mu \mathrm{m}$ in the insert.

sting apparatus was immediately dissected by pulling the sting shaft with forceps (workers), or by cutting (queens). The sting apparatus was then fixed in cold glutaraldehyde for $1 \mathrm{~h}$, then transferred to cold buffer for $10 \mathrm{~min}$ washed in buffer and stored in fresh buffer before been air mailed to Belgium. There the samples were postfixed in osmium tetroxide, and then dehydrated in a graded acetone series before 
embedding in Araldite resin. Longitudinal serial semi-thin $1 \mu \mathrm{m}$ sections were made with a Reichert Ultracut $\mathrm{E}$ instrument.

The general sting morphology and position of the associated glands were studied under a Leica light microscope and drawing made using a camera Lucida.

\section{RESULTS}

Both the exits of the venom sac and Dufour gland approach the base of the sting bulb. However, where the venom sac opens directly into the base of the sting bulb the Dufour gland narrows before exiting between the sting lancets (Fig. 1). The exit is very narrow and indistinct, which explains the confusion in the literature and inability to observe the exit using a binocular microscope (×60). In A. mellifera and $A$. cerana the Dufour gland exit is in the same position in both workers ( $\mathrm{n}=3$ of each species) and queens ( $n=3$ of each species).

\section{DISCUSSION}

This study provides the first clear evidence that the glands exit is through the membrane between the sting lancets, and is the same in queens and workers in both $A$. mellifera and $A$. cerana. Our observation are similar to those of Billen (1987) who found that in both queens and workers the Dufour gland approaches the sting base along with the venom gland, but bends downwards and opens into what he called the 'dorsal vaginal wall'. During oviposition the egg does not pass directly over the exit of the Dufour gland and it is therefore unlikely that the gland in involved in producing an egg coating (Snodgrass, 1925), or egg marking pheromone (Ratnieks, 1995).

Some speculation still surrounds the precise role of the Dufour gland in the honey bee. However, it is known to secrete, but not produce, hydrocarbons (Katzav-Gozansky et al., 1997a) which are used for waterproofing the cuticle and possibly involved in chemical communication (Abdalla and Cruz-Landim, 2001). In addition to the hydrocarbons the queens' Dufour gland secrete a series of esters (KatzavGozansky et al., 1997b; Martin et al., 2002) which function as part of the multi-sourced queen signal (Katzav-Gozansky et al., 2003), while the workers Dufour gland secrete eicosenol (Martin et al., 2004) a low volatile alarm pheromone (Pickett et al., 1982). This may explain why workers are attracted by virgin queen Dufour gland extracts and repelled by worker Dufour gland extracts (Abdalla and Cruz, 2001). As both esters and eicosenol act as pheromones in the honeybees this confirms the idea that the Dufour gland secretions are utilised in defence by workers or reproduction in queens. This is consistent with the position of exit of the gland which allows the glands secretions to be deposited on the setosa membrane, a hairy region of cuticle which surrounds the entire sting bulb and acts as a platform for pheromone release (Lensky et al., 1995).

Résumé - Morphologie de la glande de Dufour au sein du complexe de la glande à venin des abeilles mellifères (Apis spp.). La glande de Dufour est associée à l'appareil vulnérant chez toutes les femelles d'Hyménoptères. Il s'agit d'une structure utilisée par les ouvrières pour défendre le nid et par la reine pour se reproduire. Malgré plusieurs études le débouché précis de la glande de Dufour chez les abeilles mellifères (Apis spp.) reste inconnu. Cette connaissance est pourtant importante puisque, d'un point de vue historique la fonction de la glande a été basée sur la position de son débouché. Afín de mieux comprendre le rôle de cette glande, nous avons mené une étude morphologique pour connaître avec précision où elle débouchait. Des butineuses et des reines d'Apis mellifera et d'Apis cerana ont été prélevées à Sheffield (UK) et à Matsumoto (Japon). L'appareil à venin a été fixé dans du glutaraldéhyde, puis postfixé dans du tétroxyde d'osmium et monté dans de l'araldite. On a fait ensuite des séries de coupes longitudinales de $1 \mu \mathrm{m}$ de section. La glande de Dufour se rétrécit et devient indistincte avant de déboucher entre les soies de l'aiguillon (Fig. 1). La glande débouche au même endroit chez les ouvrières et les reines des deux espèces. La glande de Dufour des reines sécrète une série d'esters qui participent au signal de la reine, tandis que la glande de Dufour des ouvrières sécrète de l'eicosenol, qui est une phéromone d'alarme. Le fait que les esters et l'eicosenol agissent en tant que phéromones confirme l'idée que la position du débouché de la glande permet l'émission et le dépôt des secrétions la membrane sétacée, région pileuse de la cuticule entourant tout le bulbe de l'aiguillon et pouvant servir de base pour la libération des phéromones.

Apis mellifera / Apis cerana / glande de Dufour / aiguillon / morphologie 
Zusammenfassung - Morphologie der Dufourschen Drüse im Stachelapparatkomplex der Honigbiene. Die Dufoursche Drüse ist bei allen Hymenopterenweibchen mit dem Stachelapparat assoziiert, ein Strukturkomplex der bei Arbeiterinnen der Nestverteidigung und bei Königinnen der Reproduktion dient. Trotz vielfacher Studien ist die genaue Lage des Ausführgangs der Dufourschen Drüse bei Honigbienen bislang ungeklärt. Diese Kenntnis ist jedoch wichtig, da die Funktion von Drüsen historisch gesehen stets im Kontext mit der Lage des Ausführgangs interpretiert wird. Als Material gewannen wir Apis mellifera und Apis cerana Sammlerinnen und Mutterköniginnen aus Sheffield, England, und Matsumoto, Japan. Der jeweilige Stachelapparat wurde in Glutaraldehyd fixiert, in Osmiumtetroxid nachfixiert und in Araldit-Harz eingebettet, bevor serielle Semidünnschnitte von $1 \mu \mathrm{m}$ angefertigt wurden. Die Dufoursche Drüse verengt sich und endet zwischen den Stachellanzetten (Abb. 1). Der Drüsenausgang liegt bei Königinnen und Arbeiterinnen beider Arten in der gleichen Position. Sowohl Ester, die Teil des Königinnensignals sind, und Eicosenol, ein Alarmpheromon, werden von der Dufourschen Drüse produziert. Da beide Komponenten Funktionen als Pheromone haben, bestätigt dies die Annahme, dass die Position des Ausführgangs die Abgabe und Deposition des Sekrets auf der Stachelscheide ermöglicht, einer behaarten Cuticularegion, die den gesamten Stachelbulbus umgibt und als Basis der Sekretfreisetzung dienen kann.

\section{Apis / Honigbiene / Dufoursche Drüse / Stachel}

\section{REFERENCE}

Abdalla F.C., Cruz-Landim C. (2001) Behavioral responses evoked in honey bee workers by Dufour gland extracts (Hymenoptera: Apidae), Sociobiology 37, 673-678.

Bettini S. (1978) Arthropod venoms, Springer, Berlin-Heidelberg-New York.

Billen J.P.J. (1987) New structural aspects of the Dufour's and venom glands in social insects, Naturwissenschaften 74, 340-341.

Carlet G. (1890) Mémoire sur le venin et l'aiguillon de l'abeille, Ann. Sci. Nat. Zool. 7 ser. 9, 1-17.

De Lello E. (1976) Adnexal glands of the sting apparatus in bees: Anatomy and histology, V
(Hymenoptera: Apidae), J. Kansas Entomol. Soc. 49, 85-99.

Dufour L. (1835) Études entomologiques. VII. Hyménoptères, Ann. Soc. Entomol. Fr. 4, 594 607.

Gunnison A.F., Morse R.A. (1968) Source of the ether-soluble organics of stings of the honey bee, Apis mellifera L. (Hymenoptera: Apidae), Ann. Entomol. Soc. Am. 61, 5-8.

Heselhaus F. (1922) Die Hautdrüsen der Apiden und verwandter Formen, Zool. Jahrb. Anat. Ontogen. 43, 369-464, pls, 12-22.

Katzav-Gozansky T., Soroker V., Hefetz A. (1997a) The biosynthesis of Dufour's gland constituents in queens of the honeybee (Apis mellifera), Invertebr. Neurosci. 3, 239-243.

Katzav-Gozansky T., Soroker V., Hefetz A., Cojocaru M., Erdmann D.H., Francke W. (1997b) Plasticity of caste-specific Dufour's gland secretion in the honeybee (Apis mellifera L.), Naturwissenschaften 84, 238-241.

Katzav-Gozansky T., Soroker V., Francke W., Hefetz A. (2003) Honeybee egg-laying workers mimic a queen signal, Insectes Soc. 50, 20-23.

Lensky Y., Cassier P., Tel-Zur D. (1995) The setaceous membrane of honey bee (Apis mellifera L.) workers' sting apparatus: structure and alarm pheromone distribution, J. Insect Physiol. 41, 589-595.

Martin S.J., Jones G.R., Châline N., Middleton H., Ratnieks F.L.W. (2002) Reassessing the role of the honeybee (Apis mellifera) Dufour's glands in egg marking, Naturwissenschaften 89, 528-532.

Martin S.J., Châline N., Jones G., Oldroyd B., Ratnieks F. (2004) Egg marking pheromones of anarchistic worker honeybees (Apis mellifera), Behav. Ecol. 15, 839-844.

Pickett J.A., Williams I.H., Martin A.P. (1982) (Z)11-eicosen-1-ol, an important new pheromonal component from the sting of the honey bee Apis mellifera (Hymenoptera, Apidae), J. Chem. Ecol. 8, 163-175.

Ratnieks F.L.W. (1995) Evidence for a queenproduced egg-marking pheromone and its use in worker policing in the honey bee, J. Apic. Res. 34, 31-37.

Snodgrass R.E. (1925) Anatomy and physiology of the honey bee, The Maple Press company, NY, USA.

Trojan E. (1930) Die Dufoursche Drüse bei Apis mellifera, Z. Morphol. Ökol. Tiere 19, 678-685. 